\title{
Some Implications of Hermeneutical Readings for the Study of the Qur'an
}

\author{
Kusmana $^{1}$
}

\begin{abstract}
Hermeneutics opens up possibilities to understand something as comprehensive as possible, and at the same time, as various as possible. There can be as many readings as the number of readers or even more readings than the number of the readers as they can deploy different points of views, approaches and methods in one object. This article formulates the question of what implications does hermeneutical reading for the study of the Qur'an may have? While the result of hermeneutical reading can be as productive as possible accordingly, its implications are of variety. However in this article, two implications will be discussed: one implication on scientific necessity and the other is on productivity of reading. Two cases will be discussed here: the Qur'än as textus receptus and as discourse.
\end{abstract}

\begin{abstract}
Abstrak
Hermeneutika membuka kemungkinan-kemungkinan untuk memahami sesuatu sekomprehensif mungkin, dan, pada saat yang sama, sebanyak mungkin. Adalah memungkinkan terdapat banyak pembacaan sebanyak jumlah pembaca atau bahkan lebih banyak pembacaan dibandingkan jumlah pembaca karena mereka menggunakan berbagai perspektif, pendekatan dan metode dalam mengkaji suatu objek. Selanjutnya, apa implikasi yang mungkin ditimbulkan pembacaan hermeneutis terhadap kajian al-Qur'ān? Oleh karena hasil bacaan hermeneutis bisa sangat produktif, implikasinya bisa banyak. Dalam artikel ini, dua implikasi akan didiskusikan: satu implikasi tentang keharusan saintifik dan yang kedua tentang produktivitas pembacaan. Dua kasus akan didiskusikan di sini, yaitu al-Qur'ān sebagai textus receptus dan sebagai wacana.
\end{abstract}

1 Dosen Fakultas Ushuluddin UIN Syarif Hidayatullah Jakarta. E-mail: kusmana_k@yahoo.com. 
Keywords: Hermeneutics, Textus Receptus, Discourse, Phronesis, Kitāb al-Hidāyah, al-Hudūd.

\section{Introduction}

Different approaches to the Qur'ānic studies have been developed by scholars, and each of its approach has its own implication. For example, according to Adis Duderija, ${ }^{2}$ approaches to the Qur'ān (and Hadith) studies are divided into two only: textual and contextual approach. On the other hand, Yusuf Rahman points out that Duderija uses Abdullad Saeed's classification of approaches to the interpretation of the Qur'ān. He explains that the textualist approach argues "for a strict following of the text and adopt a literalistic approach to the text," and the contextualist approach argues for the importance of socio-historical context (past context) and present context, in addition to searching for linguistic meanings. ${ }^{3}$ Duderija uses them to discuss Salafī s approach where he includes it as pre-modern approach and progressive Muslim's approach which he calls it as critical-progressive approach. He discusses some interpretational assumptions of the Salafi's approaches. He also identifies a number of standards, methodologies and principles which put strong emphasis on maintaining the meanings of the Qur'an, intended by God as nearest as possible. ${ }^{4}$ In contrast, he asserts that critical progressive approaches have interpretational assumptions which are basically seen as "culturally produced without denying its Divine origin and status," and they search for significance and relevance of the meanings of the Qur'ān with humanity. Both approaches give contrast implications in processes and results as he illustrates in the case of divorce for husband and wife for instance, where the interpretation of literalist is claimed to have discriminative impulse to woman whereas progressive approach is claimed to have more equal one towards woman. ${ }^{5}$

2 Adis Duderija, Constructing a Religiously Ideal 'Believer' and 'Woman' in Islam: Neo-Traditional Salafí and Progressive Muslim Methods of Interpretation (New York: Macmillan, 2011).

${ }^{3}$ Yusuf Rahman, "Penafsiran Tekstual dan Kontekstual terhadap al-Qur'ān dan Hadith (Kajian terhadap Muslim Salafi dan Muslim Progressif) in Journal of Qur'ān and Hadith Studies, 1, No. 2 (January-June 2012): 297-298.

4 Adis Duderija, "Pre Modern and Critical Progressive Methodologies of Interpreting the Qur'ān and the Sunnah" in Journal of Qur'ann and Hadith Studies, 1, No. 2 (January-June 2012): 193.

${ }^{5}$ Duderija, "Pre Modern and Critical Progressive Methodologies of Interpreting the Qur'ān and the Sunnah," 194. 
The same phenomena can be seen from other perspectives with different implications too. This article is another effort of explaining theoretically the productive reading to the Qur'an. Here, is discussed some implications of productive hermeneutical reading for Qur'ānic studies. To begin with, three key terms are discussed as follows:

\section{The Qur'ān, Hermeneutics and Science}

What implications the hermeneutical reading would have for the study of the Qur'an in terms of scientific necessity? One way to answer this question is by discussing at least the nature of the three key terms and their relations: hermeneutics, science and the Qur'ān. The way hermeneutics sees an object and the object itself in the hermeneutical studies are different from the way science sees it and its object. Hermeneutics studies text and discourse within humanistic areas of studies, or if it deals with science, it examines the object within humanistic aspects of natural science. Hermeneutics discusses an object as an event of understanding, focusing on how the object appeals to the reader as meaningful, significant or relevant. It means that hermeneutics considers not only the historicity of the object, but also its function and relation to the reader and contemporary context, as well as the relation with its nuances between the world of the author, the world of the reader, and its projection to future where different horizons meet and even fused. Unlike natural sciences which treat objectivity of study as the foundation of its validity, hermeneutics discusses subjectivity, objectivity and bias not as results, but as part of hermeneutical processes in gaining a clear and comprehensive reading. So, the issue is not objective or subjective or biased interpretation of a text or discourse -- and in this article of the Qur'ān--, but it is about understanding it.

Natural sciences treat objectivity through examining validity of its data, procedure or process, and its result in which it is pushed to have testable and plausible result. Meanwhile, hermeneutics treats objectivity in determining the logic and measurability of data and checks the validity of data as part of the process of making sure its logic and measurability. Hermeneutics then uses them to create a translation, an application, an understanding, and a production of knowledge. Science uses validity to test the result of a study, whereas hermeneutics uses possibility to do so. Science seeks for objective knowledge, and hermeneutics looks for information which may be called Phronesis ${ }^{6}$ in

${ }^{6}$ Jean Grondin, "Gadamer's Basic Understanding of Understanding," in The Cambridge Companion to Gadamer, edited by Robert J. Dostal ( Cambridge: Cambridge University Press, 2002), 38. 
Aristotelian term or practical wisdoms or practical knowledge. Hermeneutics is about understanding, and understanding is wisdom ${ }^{7}$ and not scientific knowledge. In other words, hermeneutics uses scientific procedure, result, or operation system to help hermeneutical reading understand the nature of the object and seek for significance and relevance.

Before using hermeneutics in this awareness for the study of the Qur'ān, it would be helpful if we determine in what understanding the term al-Qur'an is dealt here? Qur'ānic studies (and also Hadith studies) is part of humanities studies, so hermeneutics can be applied to it. The nature of the Qur'ān is different from the nature of texts in general, because of its divine character. But the function of it is basically the same with the function of text in general, i.e. for human purposes. Putting the Qur'an in the view of modernists' conviction such Muhammad 'Abduh, as Kitāb al-Hidāyah (Book of Guidance) ${ }^{8}$, the Qur'ān is always treated by Muslims as meaningful, significant and relevant in guiding their life. The application of hermeneutical analysis in the Qur'ān as Kitāb alHidayah accordingly focuses on its significance for Muslims' life. The term Hidayah basically means guidance or showing the way to. ${ }^{9}$ As long as the message of the Qur'ān can be used as guidance and it is not contrary to Islam, an interpretation is most probably acceptable. This is a practical and pragmatic aspect of the Qur'anic studies, and it is very much the case in hermeneutics with its phronesis. This melting pot finds its relation with another key term in Islamic studies, especially in Islamic law studies, that is maslahah mursalah. This is a jurisprudential term which denotes method of deducing law from the sources of Islam which is "neither supported nor nullified by textual evidence." ${ }^{10}$ Loosely, the term is equivalent with public interest or public utility in the Western perspective. Public interest is commonly known also in the Western thinking as one of the discursive resource or point of departure to conceive things or phenomena. In Islam the term has long history of its conceptualization, referring back to the formative period of Islamic law. The Mālikis and Hanbalis adopted it in their way of deducing Islamic law. The Shāfi $\bar{i}^{\bar{s}}$ and Hanafis do not use it, but they use other terms, such as the

7 Richard E. Palmer, Hermeneutika: Teori Baru Mengenai Interpretasi (Yogyakarta: Pustaka Pelajar, 2003), 232.

8 Nasr Hamid Abu Zaid, Rethinking the Qur'an: Towards a Humanistic Hermeneutics (Utrecht: Humanistics University Press, 2004), 58.

${ }^{9}$ Rohi Baalbaki. Al-Mawrid A Modern Arabic-English Dictionary (Beirut: Dar el-Ilm lilmalayin, 1994), 1205.

10 Nazly Hanum Lubis. "Maṣlahahah Mursalah in the Thought of Muhammad 'Abduh and Rashīd Rị̣ā," in al-Jämi'ah: Journal of Islamic Studies. 42, Number 1, (2004): 135. 
extension of hidden qiyās and istihssān. In practice, both have similar functions with the functions that of istislă. ${ }^{11} \quad$ Traditional jurist laid down three measurements to apply it: social affairs, conformity with Islam, and necessity of the matter. Muhammad 'Abduh unfastens its requirements into only public utility or public interest. By doing this he tries to make sense religion with modernity or science. ${ }^{12}$ The term is actually similar with Phronesis or Hidayah in that they all consider practical wisdom. It, for example, can be used as a bridge to characterize the realm of Qur'ānic interpretation either with Islamic jurisprudence tradition or at the same time with Western philosophy tradition.

The question is what kind of reading, hermeneutics offers for understanding the Qur'ān? How it sees the Qur'ān? How it places previous readings of the Qur'ān? By deploying hermeneutical reading, various possibilities may occur in reading the Qur'ān, including possibilities of questioning, refining, or to its extreme, of proposing a replacement of the previous wisdoms for the sake of answering new problem and challenge. It is in this nature, hermeneutic reading for the study of the Qur'ān is controversial as well as inevitable.

There are at least three basic elements of a hermeneutical reading: understanding what an author means, understanding what a reader means, and understanding what a context means? Each of these elements has relation either to one or the other two elements. The first, understanding produces reproduction, the second produces productive reading. The third understanding can either be used to apply the first reading or the second one, or the convergence between the two. Understanding the third in applying the first understanding is common in romanticism hermeneutics and also in the Qur'ānic studies tradition. It is understandable, because Muslim scholars maintain their interpretation to be as near as possible to God's intention. The problem is that the reader tends to neglect the objective situation of the need and demand of his or her time when reading the Qur'ann. It is therefore the following part, the discussion will focus on productive reading in applying particularly the second understanding or the convergence by relating either to the intention of the author or to what the context informs.

\footnotetext{
${ }^{11}$ Lubis, "Maṣlahah Mursalah in the Thought of Muhammad 'Abduh and Rashid Riḍa," 138.

${ }^{12}$ Lubis. "Maṣlahah Mursalah in the Thought of Muhammad 'Abduh and Rashìd Rị̣ā," 139 dan 141.
} 


\section{The Qur'ān as Textus Receptus}

When the Qur'ān is termed as Textus Receptus, it basically means as Muṣhaf which commonly known as Muṣhaf 'Uthmānì. The Qur'ān in which Muslims are reading now is this Mushaf. The Muṣhaf was initially collected and codified in the era of Abu Bakr's short caliphate period (632-634) under the commission coordinated by Zaid ibn Thäbit. It was passed to Abū Bakr, then to 'Umar bin Khaț̣āb then to Hafṣa, 'Umar's daughter. The Muṣhaf under the Caliphate 'Uthmān bin 'Affān (644-656), was copied into several copies, done by the commission headed by the same sahăba, Zaid bin Thäbit (between 650656). The commission which consisted of four persons re-examined the existing documents, and the documents the commission had. They were collected from other Companions, and Hafșa's Imäm Muṣhaf. These copies were distributed to several important cities: Kufa, Basra, Damascus, and of course kept one in Mecca. The political dimension marked this policy as other codices were recommended to be destroyed. The Qur'ān which arrives at our time had its "definite canonization of one system of consonant and a limit placed on the variations of vowels used in the text that resulted in acceptance of seven system," or ten readings, or fourteen readings in the tenth century. It was Ibn Mujāhid (d. 935) who had a major contribution on the finite form of the Muṣhaf. Of these variations, three systems known to be existed in the course of time: those of Warsh (d. 812) from Nāfi' of Medina, Hafṣ (d. 805) from 'Āsim of Kufa, al-Dūri (d. 860) from Abū'Amr of Basra. To date, two versions are commonly used: "that of "Āsim of Kufa through Hafș, which was given a kind of official seal of approval by being adopted in the Egyptian edition of the Koran in 1924; and that of $\mathrm{Nafi}^{-}$through Warsh, which is in use in parts of Africa other than Egypt." 13

The history of Qur'anic studies in general and of Quranic interpretation in particular and even the history of Islamic sciences or sciences developed under Islamic civilization have been influenced by the Qur'an in its textual dimension. Within its divine characteristics, Muslim scholars in the course of time derived, have been deriving messages, inspirations, values, laws etc., from it. One dimension of taking advantages of the Qur'ān as text is explaining, interpreting and understanding it within the constraints of its textuality, be it inclusive or exclusive interpretation. Subjective, biased, or ideological interpretation may be resulted from taking the Qur'ān as text as reflected from Muslims' works on interpretation of the Qur'ān. For example Mahmud Basuni

${ }^{13}$ Ibn Warraq (ed.), The Origins of the Koran: Classic Essays on Islam's Holy Book (New York; Prometheus Book, 1998), 11-16. 
Faudah discusses the history of interpretation of the Qur'an from the early period up to his time in 1970 s. $^{14}$

As in its modern development, hermeneutics ideally is used to avoid biased or ideological interpretation of a text. So, when hermeneutics is applied to interpretation of the Qur'an, it means that an interpreter tries to avoid exclusive, biased and ideological reading of the Qur'ān. How it operates if the Qur'ān is only seen as a text. Recent method of interpretation of the Qur'an such as thematic may assist in providing information to describe the intention of God through interpretation of verse or verses of the Qur'ān by the Qur'ān (another or other verses of the Qur'ān). This method prescribes comprehensive consideration by relating a key term with related terms within the same root of the word or similar meaning with the key term. This way of analysis aims at providing a general picture or a concept in the Qur'ān with its dimensions found in its related verses and similar ones in meaning. ${ }^{15}$

The difference of this method from other methods is that this method offers comprehensive concept of something of the Qur'ān, whereas others offer incomprehensive one due to particular focus of interpretation the interpreter has. By interpolating hermeneutics as tool of analysis, an interpreter is encouraged to go further searching possibilities to understand better in every part and level of understanding. He or she looks for a concept derived from the Qur'ān. In this case, to some extent the Qur'ānic studies tradition would have considered enough to base the sources on the Qur'ān, Tradition, and other related sources such as literary documents or biographical sources with special treatment. A hermeneutics extends the sources to other kinds of either religious or secular nuances of the sources as far as they could help him or her understand the object better.

There are at least three big areas of understanding in hermeneutical processes: area of author or text, area of interpreter or reader and area of context, context of author and also context of reader. Each area is complementary one to another. In practice, however, an act of reading may fall to focus on author such as in psychological reading, or may fall to focus on the understanding of author's existence such as in phenomenological reading. The result of this reading is a reproduction or reconstruction or repetition of what an author means or in the case of the Qur'an, what God means. A note is worthy

14 See, Mahmud Basuni Faudah, Tafsir-tafsir al-Qur'an: Perkenalan dengan Metodologi Tafsir(Bandung: Penerbit Pustaka, 1987).

15 Abdul Hayy al-Farmawi, Metode Tafsir al-Mawdhu'iy: Suatu Pengantar (Jakarta: Rajawali Press, 1994), 45-46. 
here, reconstruction character of this reading though has room for criticism as the potency not to produce something new due to its principle of maintaining the truth of what supposedly claimed as the origin, it has potential contribution to uncover new situation of the origin. A case in point, Toshihiko Izutsu, a Japanese scholar, who applied semantic analysis to Qur'anic studies which he calls as Qur'ānic semantics or semantics of the Qur'ān, can be seen here hermeneutically. He defines semantics as "an analytical analysis of key terms of a language with a view that at the end this analysis will arrive at the conception of weltanschauung or worldview of society who use the language, treated not only as tool for speaking and thinking, but also more important than that as conceptualization and interpretation of the world it covers." 16

For example, he gives an instance of the term kufr. The term kufr is seen not only as a definitive centre which includes all other negative connotations, but also as an important site in the Qur'anic ethic system. Kufr generically means hidden or cover or neglect purposively virtuous deed of another. This basic meaning constitutes its generic meaning, i.e. according to him ungratefulness. This meaning in Islamic heritage in the development of sciences in Islam seems to be neglected. In fact, this meaning ungratefulness is the basic characteristic in which the Qur'ān itself explains that God has been so merciful to human beings. So, the act of unbelieving in God and in his Messenger is seen as further meaning of it. He then elaborates further the term kufr to other key terms such as an opposite of imān, related to shirk, road or cause of darkness, arrogance, debating character, fásiq, fäjir and zălim. The element of ungratefulness implies different picture of Islam by far, and it is in accordant with the general picture of Islam as a religion of peace and guidance. If we omit this meaning, explanation of the term kufr would end up with a conclusion that Islam is hateful religion. ${ }^{17}$

Another example is an approach deployed by David S Power in his Studies in al-Qur'ān and Hadith. Power finds that paying attention to the history of law of inheritance informs us important evidence on the early development how Islam discussed inheritance with the existing social practice. In this case, the body of Islamic law neglected one fundamental consideration in its initial law construction that was the Qur'anic legislation. Prior to the coming of Islam, inheritance distribution was based on seniority and not

${ }^{16}$ Toshihiko Izutsu, Relasi Tuhan dan Manusia: Pendekatan Semantik terhadap al-Qur'an (Yogyakarta: PT Tiara Wacana, 2003), 3. 287. 
handling down inheritance from a generation to another one. The offer of the Qur'ān was a shift in the way of the inheritance distribution from the culture of tribalism which was nomadic to the culture of individualism. This proposal was in accordance with the general proposal of Islam that was a change from Jāhili civilization to Islamic culture with its fundamental character, i.e. peaceful way of living. With regards to inheritance, this shift offered not only more rights for individual but also more rights for women. Seeing from this angle, inheritance distribution was actually an offer to change from old practice to new one which was more relevant with the changing development that took place in the Arab society. With this understanding, Power criticized the early development of inheritance law in Islam. ${ }^{18}$

Another issue is this question, if we have already known what God wants, what this understanding means for readers, or for contemporary context? If an interpreter does not say anything about the advantage of his or her interpretation, the question is, for what or for whom this interpretation is really projected? Hermeneutics tries to answer this question by shifting its paradigm from reproduction to production of reading. And this shift characterizes hermeneutics of shifting to reader and contemporary context. It basically opens efforts to signify the benefit of the examined text for reader and his or her audiences. Treating the Qur'ān in this direction with its constrains as text, a reader would have to make an objectification and subjectification towards the Qur'ān. Objectification is a process where a reader deploys objective consideration and procedure to gather needed and reliable information. Subjectification on the other hand, is process where a reader looks for signification and relevance of the message of the Qur'an for contemporary audiences. What is missing from thematic approach to the interpretation of the Qur'ān, for example, is this search for significance of or relevance to contemporary context. These areas are dynamics, different from time to time and from place to place. These areas are history or connotation, signification, or human, other areas are universal, eternal and static. Examples of universal value honesty, justice, punishment, reward, and examples of connotation are jailing, qișasas, guarantee, penalty, death sentence, etc. Fazlur Rahman's hermeneutics in his Major Themes of the Qur'an, is a case in point of proposing punishment which considers the demand of the age, i.e. the idea of punishment is an effort to make a criminal not to repeat his or her criminal deed. He points out that the important thing in law enforcement is identifying the ratio- legist of the Qur'ān

${ }^{18}$ David S. Power, Peralihan Kekayaan dan Politik Kekuasaan: Kritik Historis Hukum Waris (Yogyakarta: LKiS, 2001), 258-265. 
or the essence of punishment, i.e. redemption. Ways of punishment are based on circumstances which certainly dynamic from time to time and from place to place. $^{19}$

Another example of treating the Qur'ān as text is Muhammad Shahrūr, a Shirian scholar. Shahrur approaches the Qur'an as a text. He differentiates Islam and Islamization, Islam is eternal and Islamization is dynamic. What Muslims need now is a new Islamization. He means with new Islamization as an effort to reinterpret the Qur'ān. Though he was formally trained in engineering, he spent much of his spare time to fulfil his curiosity in understanding Islam, trying to answer three basic questions he repeatedly posed: What foundation that makes an authority? What foundation that makes a relation between us and others or even the state? How far our ideas can be shared in a process of reading, regarding main text of religion, in particular the Qur'ān? For him, Islam is like the Holy Book, the Qur'an, and Islamization is what is seen by people in the forms of phenomenon perceived and understood sociologically. Previous Muslims had done their job by producing usūul al-fiqh, 'ilm al-kalām, Islamic philosophy, sufism, etc. It is our turn to produce new one. In his case, he proposes his. ${ }^{20} \mathrm{He}$ finds out that there is missing thing in their efforts that is constitution, constitution which in it rights of people and state are regulated. New developments beside constitution are pluralism, civil society, democracy, opposition. The question is how these concepts are introduced to the tradition of Islam? In answering it and answering the three questions above, he spent more than twenty years figuring out possible answers before he came up with his thoughts. In that, he believes that the real problem of Muslim world today is democracy. How Islam can be explained and deduced democratically? He begins with the Qur'ān, exploring it hermeneutically constructing new Islam. He basically assumes that there is no synonym in Arabic language used in the structure of the Qur'ān. He figures out every single key term in the Qur'ān, analysing such terms al-Kitāb, al-Qur'ān, al-Nubuwwät, al-risālah, àyāt almutashābihāt, àyāt al-muḥkamāt, al-sab'u al-mathānī, al-ḥudūd, al-furqān etc. Of all his sophisticated analysis, Shahrur identifies the door to elaborate pluralism and democracy in the Qur'an that is in his division of legal aspects of the Qur'ān. He divides it into three areas: moral code, legal system, and rituals. Through understanding verses of the Qur'an regarding these three areas of law

${ }^{19}$ Fazlur Rahman, Tema Pokok al-Qur'an (Bandung: Penerbit Pustaka, 1983), 70-71.

${ }^{20}$ Muhammad Syahrur, "Pendekatan Baru dalam Membaca Teks Keagamaan,” in Hermeneutika al-Qur'an: Madhab Yogya (Yogyakarta: Islamika and ForStudia, 2003), 269-270. 
he concluded that there is pluralism and democracy in the Qur'ān. In this case he proposes theory of al-hudüd or Limit. Unlike other Muslim thinkers who see the possibility to other sources outside the Muṣaf, Shahrur accepted the Qur'an as Muṣaf as we read now and reinterpret the meaning of the structure of the Qur'an putting information on punishment which schematizes as the maximal limit and the minimal limit. Death penalty is maximal limit and we can apply lower penalty based on one's guilty and situation. And there is also minimal limit such as lawfulness for someone to marry which is within mahărim al-nikăh. With this schema Muslim actually, according to him need not any fatwa, but Muslims need istifta ${ }^{-}$, or referendum. ${ }^{21}$ So, democracy is applicable in Muslim society.

\section{The Qur'ān as Discourse}

In general, the term discourse can mean either of the two meanings: in formalist view, discourse may defined as "language above the sentence," and in functionalist view, it may be defined as "language in use." 22 Regarding the former definition, the reader tries to find information larger and more extended than a sentence can inform. Included to discourse analysis is looking for cohesion, narrative, causality and motivation of text, sentence, or event. However, some say that the formalist's definition of discourse "misses and underestimates social ideas that we may use or interpret." The functionalist defines it "not restricted to the description of linguistic form, "but covers also the analysis what people do with language and how they do with it." In this meaning, a reader in his analysis looks for information in immediate, wider, socio-political, cultural and historical context of a discourse. Even in terms of Critical Discourse Analysis, a reader can do further looking at wider frame of society and their culture where a discourse erupts. Another dimension of discourse is that it is also part of text. Text, here, has at least three dimensions: structurization (deed-thing or meaningful thing), membership in genre (a characteristic of discourse -oral and written discourse), and membership of style (an individual composition). ${ }^{23}$ In short, a discourse is about language which is used in writing such as text, describing event or practice seen from

${ }^{21}$ Syahrur, "Pendekatan Baru dalam Membaca Teks Keagamaan," 270-272.

22 John. E. Richardson, Analysing Newspapers: An Approach from Critical Discourse Analysis (New York: Palgrave Mcmillan, 2007), 22-27.

${ }^{23}$ Manfred Frank, "Interpretion of a Text," in Transforming the Hermeneutic Context, From Nietzsche to Nancy, edited by Gayle L. Ormiston and Alan D. Schrift (New York: State University of New York Press, 1990), 146-147. 
internal and external aspects which are contributively influencing to the making of it.

From the above explanation we may define the Qur'ān as discourse as effort to understand the Qur'ān either in terms of linguistic or social aspect of Qur'ānic discourse. Linguistically, the Qur'ānic discourse deals with the interrelation of language usages used in the Qur'ān. A reader in this sense pays attention to the dynamism of the Qur'anic usages seen from different linguistic points of view. Socially, the Qur'ānic discourse discusses events and practice described in the Qur'ān by plotting them in wider context. A reader in this tendency focuses on events, practices or messages described in the Qur'ān from wider context, culture and history. In practice, a reader can use this perspective separately or conjointly.

To illustrate a discourse in the Qur'ān, three cases will be discussed: Naṣr Hāmid Abū Zayd's, Mohammad Arkoun's, and 'Ali Harb's view. Abū Zaid, a decade before he passed a way, proposed what he called it as humanistic hermeneutics. He treats the Qur'ān as discourse, focusing on the internal structure of the Qur'ān. His view is the extension of his proposal about textuality of the Qur'an which he formulates it as vertical dimension of revelation; the communicative process between God and the Prophet Muhammad. Here, he extends this communication to horizontal dimension of the Qur'ān, discussing more than canonization, including process of wahy (revelation) and its socialization through $d a^{\prime} w a h$, or the living phenomenon of the Qur'ān. Seeing from this perspective, the discourse of the Qur'an embodied in its structure, with its various dimensions: "dialoguing, debating, augmenting, accepting and rejecting, not only with pre-Islamic norms, practice and culture, but with its own previous assesments, presupposition, assertion, etc." ${ }^{24} \mathrm{He}$ holds that the Qur'ān uses previous or existing discourse as media to send the message of the Qur'ān. For example, in its way of communication the Qur'ān illustrates its message about punishment using the previous and contemporary social practice of punishment. Establishing justice through the implementation of qișa $\bar{s}$ is a way of punishment known to people at the time of revelation. The nature of the message of the punishment in the Qur'an is to make a criminal away from conducting criminality in the future. As the practice known by the people, they could accept the message of the Qur'ān. This way of explanation, he infers that as the circumstances today have changed, more options of methods of punishment and at the same time human rights have been constitutionalized. So the demand of the age, is that these circumstances will

${ }^{24}$ Abu Zaid, Rethinking the Qur'ān: Towards a Humanistic Hermeneutics, 7-12. 
signify religion better. This proposal, of course does not neglect opportunity to forgive as a media to solve problem, and at the same time we do not use this alternative easily as justice in Islam as in other religions is highly respected. ${ }^{25}$

To illustrate further, Abū Zaid, after defining what the Qur'ān as discourse means, discusses the structure of his humanistic hermeneutics in which he explains the Qur'an as text versus as discourse where he shows the possibility of extension in areas and meanings is a discourse, and how reconstruction and manipulation of text happened, in which he demonstrates different factual information needed to be taken into consideration to come up with new meanings. He then discusses nine characteristics of the Qur'an as discourse: polyphonic, dialogue, negotiation, deconstruction of Sharí $\overline{\bar{l}} a$, the context of modernity demand, rethinking tradition, rethinking consensus, rethinking Sunnah and Hadith, and rethinking the Qur'ān. The Qur'ān has not only one reading but many or polyphonic and they imply different meanings. The Qur'ān also uses a dialogue technique to send its message. As the Qur'ān develops some kind of diplomacy, it also negotiates its message with the people to increase its acceptance by them. The following terms: tradition, consensus, Sunnah and Hadith were constructed through the intervention of human being, their contents consists of continuity and change as human being change also. It is therefore, re-visitation of understanding them is always needed from time to time to come up with new significance and relevance. Finally, interpretation of the Qur'an is also limited as they are the product of human being. As circumstances change in a course of time, new interpretation will be always needed to answer new problems.

The whole element of his concept of the Qur'an as discourse aims at proposing new readings and new answers. As Abū Zaid sees the discourse from internal the Qur'ān, external aspects which are dynamic from time to time and place to place are put as inputs to relate what the Qur'ān really inform about the subject matter. By doing this, Abū Zaid anchors his theoretization of the Qur'ān plausible. However, his proposal needs to be applied as well as studied further.

Having discussed Abū Zaid's proposal of the Qur'ān as discourse, it is easier to summarize his hermeneutical thought in scheme in which I had made elsewhere. The scheme is illustrated below: ${ }^{26}$

${ }^{25}$ Abu Zaid, Rethinking the Qur'ān: Towards a Humanistic Hermeneutics, 35-37.

${ }^{26}$ Kusmana. "Hermeneutika Humanistik Nasr Hamid Abu Zayd: Mendiskusikan al-Qur'an sebagai Wacana" in Kanz Philosophia: A Journal for Islamic Philosophy and Mysticism, 2, No. 2, (2012): 280-288. 


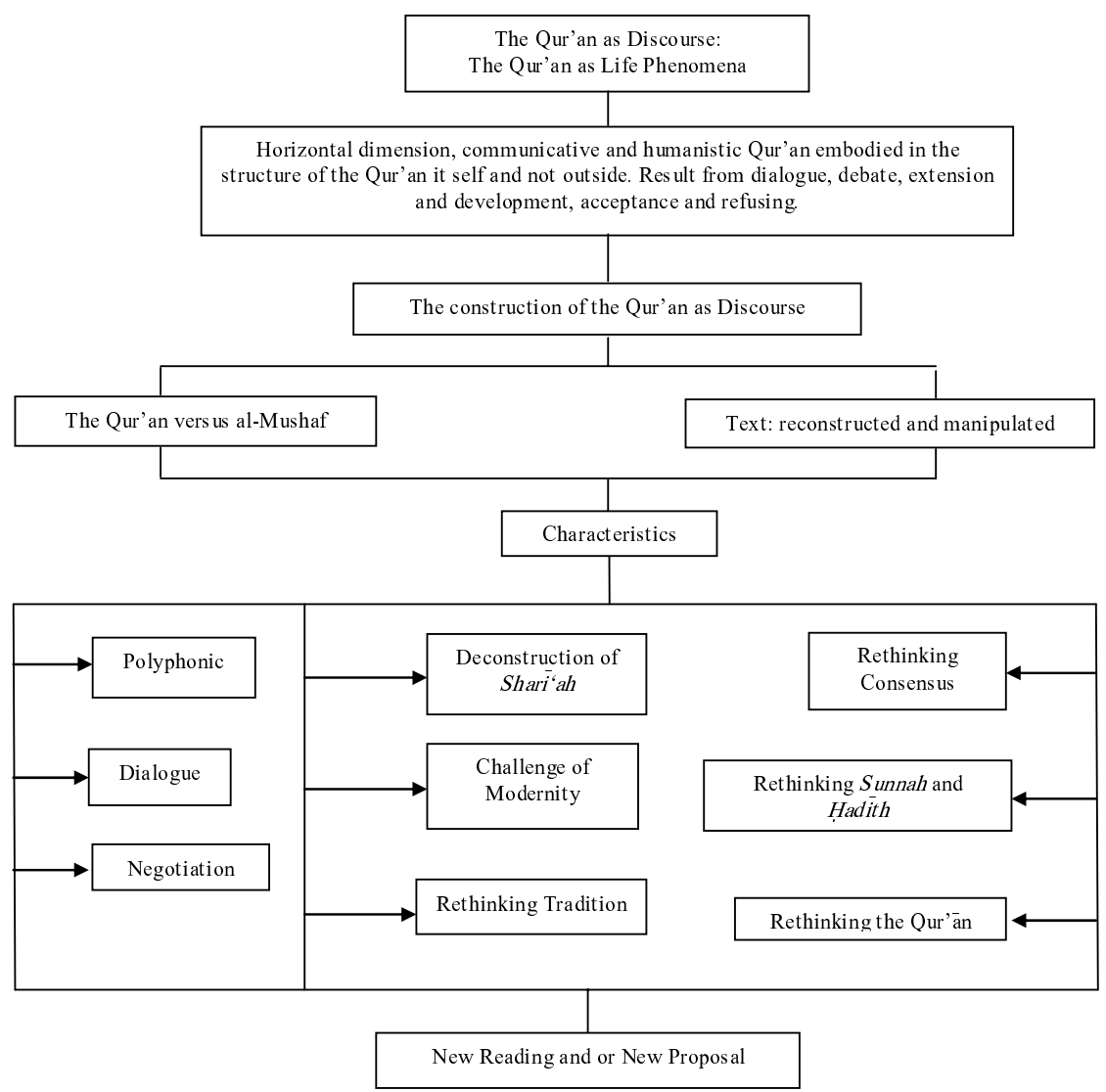

Mohammad Arkoun, an Algerian scholar, proposes what he calls as an applied Islamology, ${ }^{27}$ using an interdisciplinary approach in Islamic studies in general and Qur'anic studies in particular. As Izutsu who was deliberately not using hermeneutical terminology but had hermeneutical awareness in the application of his approach, Arkoun seems to take a similar way and his applied Islamology characterizes it as part of critical approach to the study of Islam. He reads history of thought in Islamic society in terms of competing dicourses. He understood discourse more in the sense of "language in use" rather than "language above the sentence." He interprets his search for "what really happened?" in the history of Islamic thoughts, looking for new answer. He explains that “... critical study in Islamic thougths which is applied step by step

${ }^{27}$ M. Arkoun, Membedah Pemikiran Islam (Bandung: Penerbit Pustaka, 2000), vi. 
brings about a comprehensive rethinking of religious problem." ${ }^{28}$ So, he understands discourse as critical and comprehensive. He explains three conditions to fulfil it. First, in relation to tradition in Islam, critial approach means adopting and adapting scientific method applied in the West to handle their problem. This step makes possibility for Muslim scholars to reform Islamic thoughts. Second, critical approach marks a decision and capability to indentify living phenomenon of tradition and various factors of modernity which are free and alienate human being. This step aims at avoiding misunderstandings regarding the conflict betwen tradition and modernity. Third, critical approach necssitates Islamic thought to be open totally and for the first time, towards various traditions which were reduced as minor and marginal in Islamic world such as cultural traditions of Arab, Turk, Iran and Berber. Reconsidering information from these traditions would help us understand the role of history and significance of religion for human civilization. In short, what Arkoun tries to do is demithologization and deideologization of Islamic thoughts in order for Muslim to reform their thought and civilization. $^{29}$

An example of his findings after discussing introduction to traditional Islamic thought is that Muslims have always been putting priority of Islamic civilization on the relation among God, Human being and nature, and this in the course of history becomes limitations of area and opportunity where Muslims as human being always think and act within these constrains. It is therefore, in its open attitude and civilization, according to Arkoun, the dimensions of Muslim civilizations cannot be reached by industrial civilization. ${ }^{30}$

'Ali Harb, a Lebanese scholar, offers an analysis which can go further in applying hermeneutics to the study of the Qur'ān. He suggests what he calls as naqd al-naș or critique of text. He means with it actually as critique of critique. Discourse is seen as part of the process of critique in which it is put more as hindrance or hija $b^{31}$ Using Kantian term of critique used not as tool to criticize the logic of discourse, he means with it as questioning conditions of possibility of knowledge. These questions are used to deconstruct logical categories, categories of universal rationality. ${ }^{32}$ Each category in a way avoids discussing one side about itself. For example, reason of science avoids discussing about its

28 M. Arkoun, Membongkar Wacana Hegemonik dalam Islam dan Post Modernisme (Surabaya: al-Fikr, 1999), 134.

${ }^{29}$ Arkoun, Membongkar Wacana Hegemonik, viii-ix.

${ }^{30}$ Arkoun, Membedah Pemikiran Islam, 38-39.

${ }^{31}$ Ali Harb, Kritik Nalar al-Qur'an (Yogyakarta: LkiS, 2003), 7.

${ }^{32}$ Ali Harb, Kritik Nalar al-Qur'an, 3-4. 
mythology. Similar with logical category, discourse also characterizes this when it tends to becomes hegemony. Instead, he makes a shift of paradigm from discourse of critique of reason to discourse of critique of text where he studies mechanism of discourse and its principles. ${ }^{33} \mathrm{He}$ explains nine dimensions of discourse of critique of text: texts are the same, the world of text, truth of text, strategy of text, mechanism of text, the power of text, reading of text, sophism and truth, truth and symbol. First, in his view, texts are the same in terms of critique of text. By saying this he puts the difference of a text from another in terms of content or of theme as not important. What is important here is how to construct, or to formulate a discourse and its work mechanism. The Qur'ān is treated as a language text which was constructed from a world of discourse where its language uses its own technique of metaphor. In other words, every text, be it divine text such as the Qur'ān or scientific one, has its own use of metaphor. Metaphor is always used in every usage of language of any text as it helps sending its message simpler, easier and clearer. Metaphor can be expressed in the form of body, organism, system, tool, life, construction, page and code, expression and text. ${ }^{34}$ Treated the Qur'ān as such, a reader necessitates to treat it in larger context, framework and possibility to pose questions for the sake of relevant and significant answer with the demand of age.

In the second dimension, discourse is seen from the world of text. Harb considers that in a discourse text has its world. This world is open for truth and justice. By treating this so, every reading should make possibility to find out truth and justice in his or her contemporary situation. ${ }^{35}$ The Qur'an is seen also in this dimension. Every reader when reads the Qur'ān looks actually in similar case for what is relevant and significant for his or her context. So, every reading of the Qur'ān becomes an effort to seek new answer. The third dimension, truth of text, follows up the previous dimension in that a truth as a result of a reading should be put also open and just in order to make possibility to criticize the existing truth. When this possibility is gained it actually opens also for new answer. This scheme is the nature of discourse in a critical point of view. ${ }^{36}$ The fourth dimension, strategy of text, in Harb's view has its own play and mechanism which in many cases are untold and secret. A reader is demanded to unfold and uncover this play and mechanism of a discourse represented in a

\footnotetext{
${ }^{33}$ Ali Harb, Kritik Nalar al-Qur'an, 7.

${ }^{34}$ Ali Harb, Kritik Nalar al-Qur'an, 7-9.

${ }^{35}$ Ali Harb, Kritik Nalar al-Qur'an, 9-10.

${ }^{36}$ Ali Harb, Kritik Nalar al-Qur'an, 10-12.
} 
text. ${ }^{37}$ Understanding the strategy of hindrance of text will help a reader to discover truth and justice aimed by a text. The fifth dimension, mechanism of text as explained in the previous dimension, text tends to hide its essence due to the effort of author which is limited either by his or her knowledge, aim, vested interest, ideological or scientific purposes. Reading a text should be aware of this tendency to pass over or to pass through this hindrance in order to find new answer. ${ }^{38}$ The sixth dimension, the power of text, is contingent on its play and mechanism which characterize its trap, hindrance, difference and dynamism. These dimensions determine opportunity and possibility for new reading. For example, when reading al-Ghazali's al-Munqidh min al-Ḍalāl wa al-Muwassil ila Dhí al-'Izzah wa al-Jaläl, a reader in critical reading, is suggested not to focus on what al-Ghazali addressed in his book but on what he did not address which could be the truth of the text. In this case, a reader pays attention to opportunity and possibility that al-Ghazali offered, for example about al-așlu (origin) and $a$-fur $\bar{u}^{\prime}$ (branch). Here, a reader may find that al-fur $\bar{u}^{`}$ in practice functions the function of al-aslu. ${ }^{39}$ It means that in the construction of a discourse, using hermeneutical term, there is a close relation between part and whole, and in determining one of the two a reader could fall in either position of the two. This logic of narration helps a reader to enlarge his or her reading or to find out new answer or explanation. The seventh dimension, reading text, is implication of the previous dimensions and the main focus of critical reading. It is called as productive reading even called as active productive reading. It focuses on untold story of a text including secret, difference, trap, and hindrance of what the text all about. A reader develops his or her own understanding of a text which can be resulted as a new reading, critique to it, new knowledge or new text. For example, he mentions how Althusser reads Marxism and comes up with new reading which is different from Marxian perspective, or how J. Lacoun reads Freud and comes up with new method of reading which is different from Freudian point of view. ${ }^{40}$ The eighth dimension, sophism and truth are discussed to illustrate the kind of truth, a critical reading searches for. As Harb tries in his critical reading to pass over the author, he identifies possibilities to find truth and not sophism ${ }^{41}$ by analysing categories

${ }^{37}$ Ali Harb, Kritik Nalar al-Qur'an, 13-14.

${ }^{38}$ Ali Harb, Kritik Nalar al-Qur'an, 14-17.

${ }^{39}$ Ali Harb, Kritik Nalar al-Qur'an, 17-20.

${ }^{40}$ Ali Harb, Kritik Nalar al-Qur'an, 20-23.

${ }^{41}$ The use of "clever but false argument intended to deceive." A.P. Cowie (Chief Editor), Oxford Advanced Learner's Dictionary (Oxford: Oxford University Press, 1989), $4^{\text {th }}$ Edition, 1220; it refers to sophists, "any of a number of ancient Greeks, roughly 
and deconstructing concepts developed by the author, so he is able to uncover hidden and untold story of the author of text. ${ }^{42}$ Finally, the ninth dimension, truth and symbol are discussed in term of situating the position of the reader in reading the Qur'an. Here, Harb emphasizes that in critical reading truth and symbol are seen often overlapped in their use. This is because in non-critical reading symbol is often used to hide truth. The task of reading, as he repeatedly says, is to uncover untold story or hidden information or authority. In doing so, he does not oppose the mainstream discourses, but reads them to make new possibilities for new reading. In other words, he applies a productive reading to the Qur'ān, opening new relation with it, and answering new response to the existing or new questions about it, for the sake of depth and larger scope of understanding, or proposal for replacement. ${ }^{43}$ 'Ali Harb's conception of the Qur'ān as discourse which he means it as critique of text can be drawn in a schematic way as illustrated below:

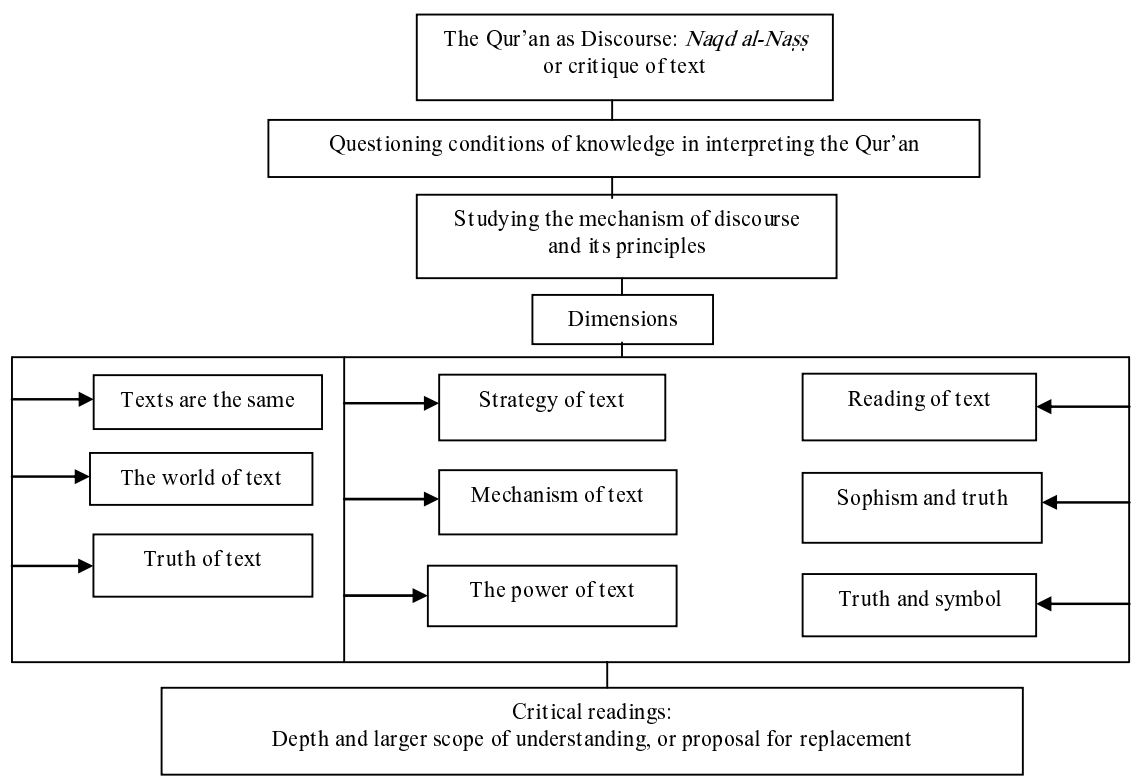

Having discussed some implications of hermeneutical reading for the studies of the Qur'ān, the discussion can be illustrated as below:

contemporaneous with Socrates who professed to teach, for a fee, rhetoric, philosophy, and how to succeed in life." Robert Audi (General Editor), The Cambridge Dictionary of Philosophy (Cambridge: Cambridge University Press, 1999), 752.

${ }_{22}$ Ali Harb, Kritik Nalar al-Qur'an, 23-25.

${ }^{43}$ Ali Harb, Kritik Nalar al-Qur'an, 26-29. 


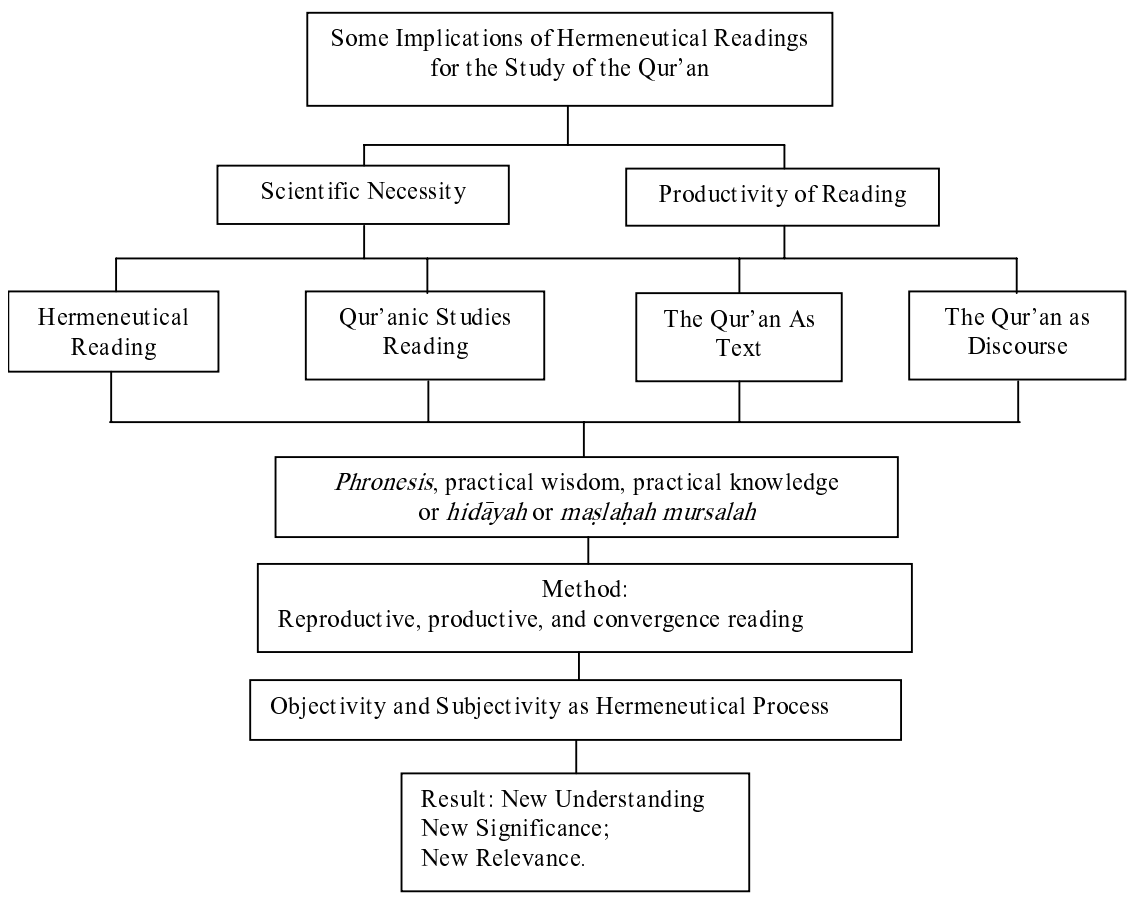

\section{Conclusion}

Discussing science, al-Qur'ān and hermeneutics requires a reposition of the relation between subjectivity and objectivity. While science measures the function of subjectivity within the effort to reach objectivity, hermeneutics puts objectivity as part of its analytical process to obtain significance and relevance of a subject matter, including the Qur'ān, and lays subjectivity as a central vehicle in a hermeneutical analysis. The target of both hermeneutics and the Qur'ānic interpretation meets on practical information, where hermeneutics looks for Phronesis (practical wisdoms) or practical knowledge and the Qur'anic interpretation searches for al-Hidāyah (Guidance) or maslahah mursalah (public utility/interest). In this window, any hermeneutical reading is open widely.

As the way of the Qur'ān was treated along its history has been always paying attention at making sure the message of the Qur'ān on the closeness to the intention of Allah, any hermeneutical reading will have the challenge to be in accordance with this spirit. It means that in the three kinds of reading: reproductive, productive and convergence between the two with tendency on productive nuance on the result side, an interpreter will always face this challenge in order his or her interpretation accepted by Muslims. With these possibilities and constraints of reading, the implications of hermeneutical 
reading for the study of the Qur'an, in one hand, follow the nature of hermeneutical reading, i.e. possible new readings and new results which extend its consideration to the search for significance and relevancy for human being, and at the same, maintains the search for God's intention. The problem then is not only on how to do a new reading, but also how to make this reading and its result is accepted. This is so because of the possibility of the extreme implication of new reading, particularly of the application of critical hermeneutical reading such as opening new relation with the object, answering new response to the existing or new questions about it with depth and larger scope of understanding, or proposal for replacement the existing concept.

The area for hermeneutical reading is vast, of the two areas discussed above, it promises new readings and results of the Textus Receptus area and that any hermeneutical reading provides either reproductive or productive reading. Reproductive reading may contribute to the possibility to explore the intention of interpreter in his or her tafsir in deeper and larger way of exploration. Whereas, productive reading may take form of pure productive reading or convergence with reproductive reading to brings new reading to the Qur'ān. Of discourse area, hermeneutical reading, on one hand, may take the form of formalist point of view where the idea of cohesion, narrative, causality and motivation of a discussed text, sentence, or event is explored. On the other hand, it may take the form of the relation between the discussed discourse with larger context, framework, culture and practice. Accordingly the implication of hermeneutical reading possibly touches the untold story, critical to the mainstream and hegemony, and even proposal for replacement as explained.

\section{Bibliography}

Abu Zaid, Nasr Hamid. Rethinking the Qur'ān: Towards a Humanistic Hermeneutics. Utrecht: Humanistics University Press, 2004.

Arkoun, Mohammed. Membedah Pemikiran Islam. Bandung: Penerbit Pustaka, 2000. First edition in France 1984.

--------. Membongkar Wacana Hegemonik dalam Islam dan Post Modernisme. Surabaya: al-Fikr, 1999. Translated from Arabic edition 1992.

Audi, Robert (General Editor). The Cambridge Dictionary of Philosophy. Cambridge: Cambridge University Press, 1999.

Baalbaki, Rohi. Al-Mawrid A Modern Arabic-English Dictionary. Beirut: Dar El-Ilm Lilmalayin, 1994. 
Cowie, A.P. (Chief Editor). Oxford Advanced Learner's Dictionary. Oxford: Oxford University Press, 1989. $4^{\text {th }}$ Edition.

Duderija, Adis. "Pre Modern and Critical Progressive Methodologies of Interpreting the Qur'ān and the Sunnah" in Journal of Qur'ān and Hadith Studies, Vol. 1, No. 2 (January-June 2012): 181-1 95.

Faudah, Mahmud Basuni. Tafsir-tafsir al-Qur'ān: Perkenalan dengan Metodologi Tafsir. Bandung: Penerbit Pustaka, 1987. 1977 first publication in Arabic.

al-Farmawi, Abdul Hayy. Metode Tafsir al-Mawdhu'iy: Suatu Pengantar. Jakarta: Rajawali Press, 1994.

Frank, Manfred. "Interpretion of a Text." In Transforming the Hermeneutic Context, From Nietzsche to Nancy. Edited by Gayle L. Ormiston and Alan D. Schrift. New York: State University of New York Press, 1990.

Grondin, Jean. "Gadamer Basic Understanding of Understanding." In The Cambridge Companion to Gadamer. Edited by Robert J. Dostal. Cambridge: Cambridge University Press, 2002.

Harb, Ali. Kritik Nalar al-Qur'ān. Yogyakarta: LkiS, 2003. Arabic edition 1995. Ibn Warraq (ed.). The Origins of the Koran: Classic Essays on Islam's Holy Book. New York; Prometheus Book, 1998.

Izutsu, Toshihiko. Relasi Tuhan dan Manusia: Pendekatan Semantik terhadap al-Qur'ān. Yogyakarta: PT Tiara Wacana, 2003. First edition in English 1997.

-------. Etika Beragama dalam Qur'ān. Jakarta: Pustaka Firdaus, 1993. Original publication 1966.

Kusmana. "Hermeneutika Humanistik Nasr Hamid Abu Zayd: Mendiskusikan al-Qur'ān sebagai Wacana" in Kanz Philosophia: A Journal for Islamic Philosophy and Mysticism. Vol. 2, No. 2, (2012): 265-290.

Lubis, Nazly Hanum. "Maṣlahah Mursalah in the Thought of Muhammad "Abduh and Rashīd Riḍa," in al-Jämíah: Journal of Islamic Studies. Volume 42, Number 1, (2004): 133-152.

Palmer, Richard E. Hermeneutika: Teori Baru Mengenai Interpretasi. Yogyakarta: Pustaka Pelajar, 2003. First edition in English 1969.

Power, David S. Peralihan Kekayaan dan Politik Kekuasaan: Kritik Historis Hukum Waris. Yogyakarta: LKiS, 2001. 1986 English Edition.

Rahman, Fazlur. Tema Pokok al-Qur'ān. Bandung: Penerbit Pustaka, 1983. English edition 1980.

Rahman, Yusuf. 'Penafsiran tekstual dan Kontekstual terhadap al-Qur'ān dan Hadith (Kajian terhadap Muslim Salafi dan Muslim Progressif) in 
Journal of Qur'ān and Hadith Studies. Vol. 1, No. 2 (January-June 2012): 297-302.

Richardson, John. E. Analysing Newspapers: An Approach from Critical Discourse Analysis. New York: Palgrave Mcmillan, 2007.

Syahrur, Muhammad. "Pendekatan Baru dalam Membaca Teks Keagamaan." In Hermeneutika al-Qur'an: Madhab Yogya. Yogyakarta: Islamika and ForStudia, 2003. 